\title{
Особливості біоелектричної активності міокарда та центральної гемодинаміки у футболісток 18-20 років у різні фази оваріально-менструального циклу
}

\author{
В. Будзин, О. Рябуха, О. Гузій
}

Львівський державний університет фізичної культури, Львів, Україна

\begin{abstract}
Резюме. Изучены особенности динамики показателей биолектрической активности миокарда и параметров гемодинамики у футболисток 18-20 лет в разные фазы овариально-менструального цикла (ОМЦ). Подтверждена зависимость деятельности сердечно-сосудистой системы от гормонального статуса женского организма. Раскрыты потенциальные возможности миокарда спортсменок.

Ключевые слова: футболистки, овариально-менструальный цикл, сердечно-сосудистая система, центральная гемодинамика.

Summary. Features of the dynamics of the bioelectrical activity of the myocardium and hemodynamic parameters in futbolistok 18-20 years in different phases of ovarian-menstrual cycle (CMC). In futbolistok 18-20 years were studied features of the dynamics of the cardiovascular system and central hemodynamic parameters in each of the phases of CMC. Confirmed the dependence of the cardiovascular system of the hormonal status of the female body. Dependence of activity of cardio-vascular system on hormonal status of female organism has been confirmed. Key words: female football-players, ovarial-menstrual cycle, cardio-vascular system, central hemodynamics.
\end{abstract}

Актуальність теми. Впродовж останніх десятиріч у фоутболі відбулися суттєві кількісні та якісні зміни - він став швидкісним, жорстким, наступальним, прагматичним і раціональним, у ньому постійно зростають фрізичні, психологічні та інтелектуальні навантаження $[1,3,8]$.

Футболу притаманне виконання динамічної роботи змінної інтенсивності, нерівномірність фрізичних та психоемоційних навантажень під час гри, непередбачувана зміна ігрових дій та пауз між ними. В основі сучасної підготовки спортсменів лежить системний підхід - синтез теорії функціональних систем та теорії адаптації, що дозволяє отримувати вагому інформацію щодо фрункціонального стану організму спортсменів впродовж тренувального процесу і використовувати отримані дані для його корекції.

Жіночий фрутбол як спортивна гра вимагає не тільки всебічної підготовки гравців, але й врахування особливостей діяльності жіночого організму. Система спортивної підготовки жінок-фрутболісток повинна відрізнятися від такої у чоловіків-фрутболістів - ії необхідно будувати 3 урахуванням біологічних особливостей жіночого організму, найважливішою з яких $є$ гормональна перебудова впродовж оваріально-менструального циклу (ОМЦ). Однак детальне вивчення функціонального стану міокарда та стану центральної гемодинаміки фрутболісток у різні фрази біологічного циклу не проводилося в достатньому обсязі.

Аналіз останніх досліджень і публікацій. Фізичні навантаження, які $€$ невід'ємною частиною занять спортом, призводять до суттєвих змін в організмі жінок-спортсменок [9, 10]. Поряд 3 цим перебіг обмінних процесів, діяльність фрізіологічних і функціональних систем спортсменок постійно зазнають циклічних змін, зумовлених специфрікою гормонального статусу в різні фрази оваріально-менструального циклу $[1,6,3$, 9]. Досліджень, присвячених 3'ясуванню особливостей діяльності певних систем організму спортсменок у різні фрази ОМЦ, є доволі багато. Так, Л. Я.-Г.Шахліна, О. Р. Радзієвськиий [9, 10], 3. Я. Яценко, Т. П. Степанова вивчали зміни діяльності респіраторної системи, центральної гемодинаміки, рівня фрізичної працездатності [9, 10]. Обстеженню підлягали спортсменки більш традиційних для жінок видів спорту - гімнастики, плавання, легкої атлетики, біатлону тощо. Водночас дуже мало досліджень, присвячених детальному вивченню показників біоелектричної діяльності міокарда та параметрів центральної 
гемодинаміки саме фрутболісток у різні фрази ОМЦ.

Мета та завдання дослідження. Визначити та охарактеризувати функціональні можливості міокарда та залежність стану центральної гемодинаміки 18-20-річних фрутболісток від гормонального статусу жіночого організму в різні фрази ОМЦ.

\section{Методи дослідження.}

1. Аналіз і узагальнення наукової та науково-методичної літератури з питань впливу гормональних змін в різні фрази ОМЦ на показники серцево-судинної системи спортсменок.

2. Параклінічні методи (електрокардіографія, тонометрія, пульсометрія).

3. Методи математичної статистики.

Організація дослідження. Розподіл специфічного біологічного циклу на фрази здійснювався у відповідності до критеріїв Н.В. Свєчнікової, згідно з якими 28-денний ОМЦ поділяється на п'ять фаз [6]. У кожну 3 фраз в обстежуваних визначали частоту серцевих скорочень (ЧСС), показники артеріального тиску (АТ), електричну активність міокарда. Електрокардіограму (ЕКГ) проводили на базі діагностичного центру Львівської залізниці у трьох функціональних станах - спокою, фрізичного навантаження (20 присідань за 30 с) і на п'ятій хвилині відновлення у положенні сидячи, тоно- і пульсометрію - у стані спокою. Фази ОМЦ верифрікували шляхом радіоімунного тестування венозної крові в радіоізотопній лабораторії Львівської обласної клінічної лікарні.

Всього обстежено 40 фуутболісток I розряду 18-20 років, які навчалися у Львівському Державному університеті фрізичної культури.

Матеріали і методи дослідження. Артеріальний тиск (АТ, мм рт ст.) вимірювали за методом Короткова механічним апаратом для вимірювання артеріального тиску моделі BP AGI-20. Визначення ЧСС (уд хВ $^{-1}$ ) здійснювалось пальпаторно на променевій артерії протягом 15 с 3 наступним перерахунком для визначення кількості ударів за одну хвилину (уд $\left.\mathrm{xB}^{-1}\right)$. Для дослідження стану центральної гемодинаміки за загальноприйнятими фрормулами [7] використовували такі показники: МхАТ (систолічний АТ), MnAT (діастолічний АT), РТ (пульсовий АТ), МуAТ (середній АТ), ХОК (хвилинний об'єм крові), СО (систолічний об'єм крові), ПСО (периферичний судинний опір), СІ (серцевий індекс), УІ (ударний індекс).

Електрокардіографрічне дослідження діяльності серця проводилось на триканальному електрокардіографрі «ЮКАРД» компанії «ЮТАС»
(Росія), з автоматичною синхронною реєстрацією 12 стандартних відведень. Аналізу підлягали амплітудні і часові параметри ЕКГ, отримані у II стандартному відведенні: амплітуда основних зубців (P, R, T) та тривалість інтервалів (P-Q, QRS,Q-T, R-R).

Для оцінювання цифрових параметрів використовували пакети статистичних програм Statistska 6.0.

Результати дослідження та їх обговорення. Результати визначень параметрів II стандартного відведення електрокардіограм орутболісток 18-20 років, представлено у таблиці 1.

Аналіз отриманих результатів показав, що впродовж ОМЦ усі досліджувані показники електрофрізіологічної активності міокарда обстежуваних перебували у межах статевої та вікової норми, а показники ЕКГ у різні фрази ОМЦ мали певні відмінності.

У I фразі біологічного циклу фрізичне навантаження не змінювало тривалості зубця Р: зростання його амплітуди було невірогідним (1,33 \pm 0,48 проти 1,18 $\pm 0,62$ мВ у стані спокою; $p>0,05)$. Під час відновлення спостерігалося вірогідне зменшення як тривалості, так i амплітуди зубця Р щодо результатів, отриманих при фоункціональному напруженні та у стані спокою $(p<0,05)$. Такі зміни тривалості й амплітуди зубця Р спостерігалися і в III фразі біологічного циклу: функціональне навантаження супроводжувалося тенденцією до збільшення обговорюваних показників ( $>>0,05)$, а у стані відновлення ці показники зменшувалися. По-іншому реагували передсердя у II та IV фразах ОМЦ: при функціональному відновленні простежувалась виразна тенденція до збільшення амплітуди зубця $\mathrm{P}$ щодо результатів, отриманих як у стані навантаження, так і у стані спокою. У V фазі ОМЦ тривалість зубця P практично не залежала від функкціонального стану обстежуваних, тоді як його амплітуда після навантаження зростала і після відпочинку не поверталася на вихідний рівень ( $p<0,05)$.

Отже, у переважній більшості випадків у футболісток фрізичне навантаження супроводжувалось зростанням амплітуди зубця Р: 1) збільшенням після фрізичного навантаження і подальшим зменшення у стані відновлення у I, III та V фразах ОМЦ внаслідок підвищення тонусу парасимпатичної нервової системи; 2) збільшенням у стані відновлення після навантаження у II і IV фразах через підсилення тонусу симпатичної нервової системи. Разом з тим підвищення впливу $\mathrm{n}$. vagus на серцевий м'яз можна розцінювати, як ознаку економізації діяльності серця при одночасному прискоренні перебігу відновних процесів 


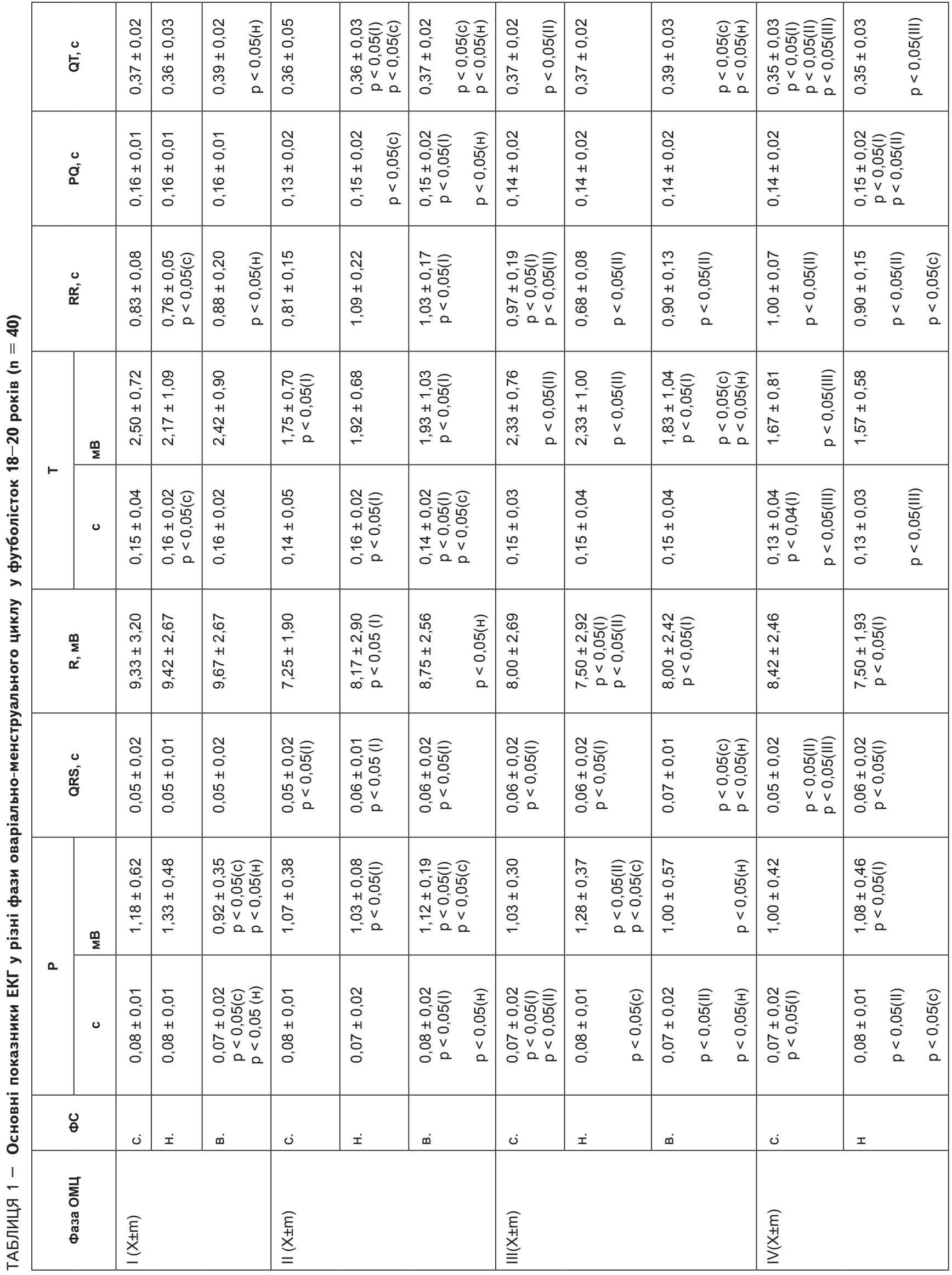


Спортивна медицина, № 1, 2014

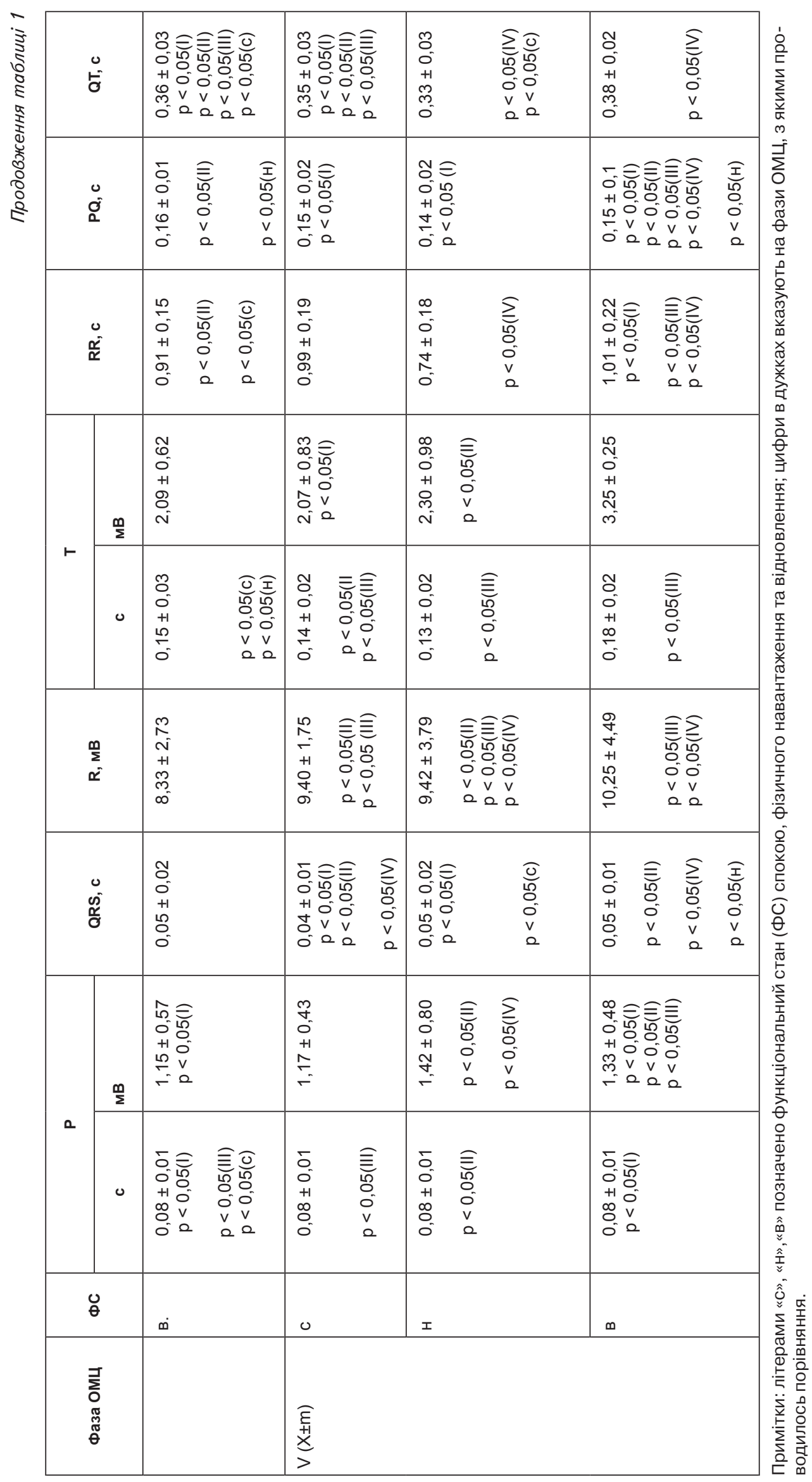


у міокарді під час «слабких» фаз біологічного циклу. Важливо зазначити, що тривалість зубця P y V фразі біологічного циклу не залежала від функціонального стану фрутболісток, що також може свідчити про потребу у включенні додаткових компенсаторних можливостей міокарда у цю фразу. Зменшення тривалості зубця Р (порівняно з даними, отриманими при функціональному навантаженні), що спостерігається у стані відновлення у I та III фразах ОМЦ, може вказувати на напруження міокарда передсердь у ці фрази циклу.

Тривалість передсердно-шлуночкової провідності у I і III фазах біологічного циклу під впливом фрізичного навантаження не змінювалася. Проте y V фразі тривалість інтервалу $\mathrm{P}-\mathrm{Q}$ після фрізичного навантаження зменшувалася $(0,14 \pm 0,02$ проти $0,15 \pm 0,02$ с у стані спокою; $p>0,05)$ і після відновлення поверталась до вихідних значень $(0,15 \pm 0,01$ c). Динаміка змін тривалості інтервалу $\mathrm{P}-\mathrm{Q}$ під час II та IV фраз ОМЦ була іншою: після фрізичного навантаження у II фразі циклу вона збільшувалась з 0,13 $\pm 0,02$ до 0,15 $\pm 0,02$ с ( $p<0,05)$, у IV фазі циклу - з 0,14 $\pm 0,02$ до $0,15 \pm 0,02 \mathrm{c} ;(p>0,05)$. В обговорювані фрази циклу тривалість передсердно-шлуночкової провідності у стані відновлення після навантаження залишалася на рівні значень, досягнутих при фрізичному навантаженні. Встановлена залежність тривалості передсердно-шлуночкової провідності від фуннкціонального стану фрутболісток вказує, що у II та IV фразах циклу в міокарді покращується проведення імпульсу з передсердь у шлуночки.

Аналіз змін амплітуди зубця $\mathrm{R}$ дозволив встановити, що у I i V фразах ОМЦ фрізичне навантаження не впливало на цей показник (відповідно $9,42 \pm 2,67$ проти $9,33 \pm 3,20$ мB та 9,42 $\pm 3,79$ проти $9,40 \pm 1,75$ мB; $p>0,05)$. У III та IV фозах циклу фізичне навантаження призводило до незначного зменшення амплітуди обговорюваного зубця $(7,50 \pm 2,92$ проти 8,00 $\pm 2,69$ мВ та 7,50 $\pm 1,93$ проти $8,42 \pm 2,46$ мВ) з подальшим відновленням до попередніх рівнів значень $(8,00 \pm 2,42$ та $8,33 \pm 2,73$ мB проти початкових $8,00 \pm 2,69$ та $8,42 \pm 2,46$ мB; $p>0,05)$. У II фразі ОМЦ після фрізичного навантаження спостерігалося збільшення амплітуди зубця R, яка продовжувала зростати і у стані відновлення (7,25 \pm 1,90 мВ у стані спокою, 8,17 $\pm 2,90$ мВ після ффізичного навантаження, 8,75 $\pm 2,56 \mathrm{mB}$ після відпочинку; $p<0,05)$. Отримані результати можуть свідчити про те, що компенсаторні механізми міокарда найбільше виявляються під час I та V фраз ОМЦ, найменше - під час його II фази.
Зміни тривалості внутрішньошлуночкової провідності (інтервал QRS) в загальних рисах повторювали зміни зубця R. Так, протягом I і III фаз біологічного циклу тривалість комплексу QRS була резистентною до фрізичного навантаження (відповідно 0,05 \pm 0,01 проти 0,05 $\pm 0,02$ с та $0,06 \pm 0,02$ проти $0,06 \pm 0,02$ с у стані спокою; р > 0,05). Під час II та IV фаз біологічного циклу навантаження призводило до ії̈ незначного збільшення щодо показників стану спокою $(p>0,05)$. Водночас якщо у II фразі ОМЦ тривалість комплексу QRS після відновлення була дещо більша, ніж його значення у стані спокою $(0,06 \pm 0,02$ проти $0,05 \pm 0,02 c ; p>0,05)$, то у IV фазі циклу вона поверталася до рівня початкових показників $(0,05 \pm 0,02$ проти 0,05 $\pm 0,02$ с). Фізичне навантаження у III фразі ОМЦ не збільшувало час внутрішньошлуночкової провідності, а після відновлення він був вірогідно більшим, ніж у стані спокою та після навантаження ( $<<0,05$ в обох випадках). Отримані результати ми вважаємо ознаками напруження компенсаторних механізмів міокарда при функціонально значущій для жіночого організму фразі біологічного циклу.

Аналіз тривалості інтервалів R-R дозволив встановити, що у III та V фразах ОМЦ після фрізичного навантаження відбувалось їх помірне зменшення, яке пов'язане з прискоренням ЧСС, а після п'ятихвилинного відновлення - помірне збільшення (в усіх випадках р > 0,05), що закономірно збільшує навантаження на серцевий м'яз і серцево-судинну систему в цілому. У I фазі ОМЦ навантаження призводило до вірогідного зменшення щодо стану спокою, тривалості серцевого циклу $(0,76 \pm 0,05$ проти $0,89 \pm 0,08$ с; $\mathrm{p}<0,05)$ з наступним відновленням його параметрів до рівня стану спокою (щодо значення тривалості R-R у стані фрізичного навантаження $\mathrm{p}<0,05$ і у стані спокою $-\mathrm{p}>0,05)$. Одержані дані можуть свідчити, що потенційні можливості міокарда у I фазі ОМЦ є більшими, ніж у III та V фразах біологічного циклу. Динаміка тривалості інтервалів R-R після фрізичного навантаження $\mathrm{i}$ відновлення у «сильні» фрази циклу була іншою. Так, у II фразі ОМЦ навантаження призводило до ії помірного зростання щодо параметрів стану спокою ( $>>0,05)$; після відпочинку серцевий цикл повністю не відновлювався: тривалість R-R практично не відрізнялася від даних після фрізичного навантаження $(1,03 \pm 0,17$ проти $1,09 \pm 0,22 \mathrm{c}$; $\mathrm{p}>0,05)$. У IV фразі ОМЦ навантаження призводило до вірогідного зменшення тривалості інтервалу $R-R(0,90 \pm 0,15$ проти $1,00 \pm 0,07$ c; p < 0,05). Після відновлення тривалість серцевого циклу продовжувала перебувати на 
рівні, визначеному після фрізичного навантаження $(0,91 \pm 0,15$ проти $0,90 \pm 0,15 \mathrm{c} ; \mathrm{p}>0,05)$ (див. табл. 1).

Отже, в III та IV фразах ОМЦ на п'ятій хвилині відновлення у міокарді спостерігається тенденція до посилення відновних процесів. Збільшення щодо параметрів стану спокою тривалості інтервалу R-R після фрізичного навантаження та відпочинку у II фразі ОМЦ ми розцінюємо, як ознаку впливу n.vagus на систему кровообігу після фрізичного навантаження. На противагу цьому помірне зменшення після фрункціональної проби тривалості інтервалу R-R, яке спостерігається у IV фразі циклу, можна вважати однією з ознак адаптації серцево-судинної системи до фрізичного навантаження.

Електрична систола серця (інтервал Q-T) в нормі перебуває у широких межах. Тривалість інтервалу Q-T вважають об'єктивним показником функціональних можливостей серцевого м'яза: її збільшення, зумовлене тахікардією, свідчить про порушення координації функцій міокарда внаслідок напруження. Такі зміни ми помічали на ЕКГ фрутболісток у І фразі ОМЦ $(0,37 \pm 0,02$ с при ЧСС 72 уд хв$^{-1}$ у стані спокою та 0,36 $\pm 0,03$ с при ЧСС 79 уд хв $^{-1}$ після навантаження). В інші фрази біологічного циклу тривалість інтервалу Q-Т відповідала ЧСС, що є сприятливою ознакою.

Результати проведеного аналізу змін біоелектричної активності міокарда підтвердили, що функціонально фрази ОМЦ поділяють на «сильні» i «слабкі». Водночас і ті, й інші $є$ однорідними. Так, I i V фрази ОМЦ у фрутболісток характеризувалися більшими потенційними можливостями міокарда, ніж III фраза, у якій спостерігалися ознаки напруження компенсаторних механізмів передсердь. Разом з тим у I фразі циклу було виявлено порушення координації діяльності міокарда і його недостатня здатність до відновлення після фрізичних навантажень, а у V фразі - внаслідок зменшення резервних можливостей шлуночків - виразно простежувалася потреба у включенні додаткових компенсаторних механізмів. Встановлено, що у функціонально «сильні» фрази біологічного циклу передсердно-шлуночкова провідність була кращою, ніж у фрункціонально «слабкі», а прояви дії компенсаторних механізмів у міокарді - меншими; у IV фразі біологічного циклу потенційні можливості міокарда були більшими, ніж у II фразі.

Для детальнішого обстеження серцево-судинної системи було визначено стан центральної гемодинаміки. Результати дослідження коливань показників центральної гемодинаміки у різні фрази біологічного циклу, представлено у таблиці 2.

Дослідження показали, що фонові дані ЧСС футболісток впродовж усього біологічного циклу були у межах вікової та статевої норми. Водночас встановлено фразові коливання: 1) найбільші показники ЧСС спостерігалися у V фразі циклу $\left(74,33 \pm 7,34\right.$ уд хв$\left.^{-1}\right) ; 2$ ) з фрази I до III відбувалося прогресуюче зменшення параметрів ЧСС (відповідно 69,10 \pm 5,59 уд $\cdot$ хв$^{-1}$ у фразі I, $65,90 \pm 6,38$ - у фразі II, 63,90 \pm 4,83 - у фразі III, причому різниця параметрів фраз I та III була статистично вірогідною ( $<<0,05)$; 3) з фрази IV починалось інтенсивне зростання ЧСС (у IV фразі були вірогідно більшими, ніж у III і II фразах; в

ТАБЛИЦЯ 2 - Показники центральної гемодинаміки футболісток 18-20 років у різні фази (I-V) оваріально-менструального циклу $(X \pm m, n=40)$

\begin{tabular}{|c|c|c|c|c|c|}
\hline \multirow{2}{*}{ Показники } & \multicolumn{5}{|c|}{ Фази ОМц } \\
\hline & 1 & II & III & IV & v \\
\hline ЧСС, уд $\cdot$ хв $^{-1}$ & $69,10 \pm 5,59$ & $65,90 \pm 6,38$ & $63,90 \pm 4,83(I)$ & $70,37 \pm 6,50(\mathrm{I}, \mathrm{III})$ & $\begin{array}{c}74,33 \pm 7,34 \\
(\mathrm{I}, \mathrm{II}, \mathrm{IV})\end{array}$ \\
\hline $\begin{array}{l}\text { МпАТ, } \\
\text { мм рт. ст. }\end{array}$ & $65,83 \pm 5,10$ & $65,33 \pm 5,07$ & $63,67 \pm 5,56$ & $67,33 \pm 4,10$ (III) & $60,67 \pm 3,88(\mathrm{I}, \mathrm{III})$ \\
\hline $\begin{array}{l}\text { PT, } \\
\text { мм рт. ст. }\end{array}$ & $48,83 \pm 6,25$ & $49,00 \pm 6,87$ & $43,67 \pm 7,06(\mathrm{I}, \mathrm{III})$ & $45,67 \pm 6,91$ & $48,67 \pm 6,9$ (II) \\
\hline $\begin{array}{l}\text { МуAT, } \\
\text { мм рт. ст. }\end{array}$ & $85,79 \pm 5,34$ & $86,59 \pm 4,87$ & $82,44 \pm 5,78(\mathrm{I}, \mathrm{III})$ & $86,97 \pm 4,45$ & $81,53 \pm 4,80(\mathrm{I}, \mathrm{II})$ \\
\hline СО, мл & $73,40 \pm 5,07$ & $73,90 \pm 5,09$ & $72,15 \pm 5,53$ & $70,91 \pm 4,82(\mathrm{I}, \mathrm{II})$ & $\begin{array}{c}76,35 \pm 4,38 \\
(\mathrm{I}, \mathrm{II}, \mathrm{III})\end{array}$ \\
\hline $\mathrm{XOK,} \mathrm{мл} \cdot \mathrm{XB}^{-1}$ & $5100,74 \pm 535,53$ & $4843,01 \pm 609,91$ & $4609,14 \pm 4777,19(\mathrm{I})$ & $4922,16 \pm 612,95$ & $5683,68 \pm 709,96^{*}$ \\
\hline $\begin{array}{l}\text { 3ПОС, } \\
\text { дін } \mathrm{c}^{-1} \cdot \mathrm{CM}^{-5}\end{array}$ & $1389,77 \pm 181,43$ & $1451,57 \pm 195,87$ & $1445,66 \pm 184,10$ & $1408,65 \pm 156,98$ & $1166,10 \pm 166,63$ ( III) \\
\hline $\mathrm{Cl}, \mathrm{m} \cdot \mathrm{xB} \cdot \mathrm{M}^{-2}$ & $3221,85 \pm 379,885$ & $3083,91 \pm 355,19$ & $2958,36 \pm 345,84(\mathrm{I})$ & $3166,26 \pm 375,48$ (III) & $3633,63 \pm 492,61$ (III) \\
\hline УІ, мл $\cdot \mathrm{M}^{-2}$ & $46,42 \pm 4,53$ & $46,59 \pm 4,30$ & $46,87 \pm 6,16$ & $45,44 \pm 4,60$ & $48,18 \pm 4,18$ \\
\hline
\end{tabular}

Примітки: цифри в дужках - фаза, з якою проводилось порівняння, $\mathrm{p}<0,05$. 
обох випадках $\mathrm{p}<0,05)$; 4) показники ЧСС фрази V були більшими, ніж IV (відповідно 74,33 \pm 7,34 проти $70,37 \pm 6,50$ уд $\cdot$ хв. $^{-1} ;$ p $\left.<0,05\right)$.

Показники МхАТ в обстежених були найвищими у I, II і IV фразах (114,67 $\pm 6,81 ; 114,33 \pm 6,79$ та $113,17 \pm 7,01$ мм рт. ст. відповідно), найнижчими - y V i III фозах $(109,33 \pm 7,74$ та $107,33 \pm 8,07$ мм рт. ст.; $p<0,05)$. Дещо поіншому виглядав фразовий розподіл результатів визначення MnAT: найвищі значення спостерігалися у IV фразі (67,33 \pm 4,10 мм рт. ст.), найнижчі - y V (60,67 $\pm 3,88$ мм рт. ст.); під час I та II фраз ОМЦ параметри розподілу практично перебували на одному рівні і незначно знижувалися у III фразі циклу. Зростання цифрових значень обговорюваного показника у IV фразі циклу щодо його значення у III фразі було вірогідним $(p<0,05)$. У V фразі циклу цифрові значення систолічного тиску, порівняно з даними IV фрази, були меншими (60,67 $\pm 3,88$ проти $67,33 \pm 4,10$ мм рт. ст.).

Показник РТ у футболісток протягом I, II та V фраз майже не змінювався; найнижчі його значення зафріксовано у III фразі $(43,67 \pm 7,06$; щодо значень обговорюваного показника у I фразі $\mathrm{p}<0,05)$, з фази IV циклу параметри РТ починали зростати.

Параметр МуАТ характеризувався найвищими цифровими значеннями у II і IV фразах циклу (відповідно 86,59 $\pm 4,87$ і 86,97 $\pm 4,45$ мм рт. ст.), а найнижчі зареєстровані у V i III фразах (відповідно $81,53 \pm 4,80$ та $82,44 \pm 5,78$ мм рт. ст.; щодо значень обговорюваного параметра у II фразі в обох випадках $p<0,05)$.

Показник СО в групі фрутболісток протягом перших трьох фраз перебував практично на одному рівні. Проте у IV фразі він знизився до $70,91 \pm 4,82$ мл (щодо значення обговорюваного параметра у I фазі $p<0,05)$ з подальшим підвищенням цифрових значень до 76,35 \pm 4,38 мл у $\checkmark$ фазі циклу. Параметри ХОК також були найбільшими у $\mathrm{V}$ фразі циклу (щодо показників у I фразі $p<0,05)$; найменшими значення цього параметру були у III фразі циклу. Встановлено, що протягом ОМЦ величина обговорюваного показника хвилеподібно змінювалась від найбільшої у V фразі до найменшої у III фразі. Показники ЗПОС були найнижчими у $V$ фразі циклу, найвищими у II і III фразах, а у I та IV фразах циклу вони перебували майже на одному рівні.

Серцевий індекс (Cl) мав чітку фразову динаміку: найнижчими його цифрові значення були у III фразі $\left(2958,40 \pm 344,36 \mathrm{Mл} \cdot \mathrm{XB} \cdot \mathrm{M}^{-2}\right.$; щодо значення у I фразі $p<0,05)$. Під час I, II та IV фраз його показники коливалися у незначних межах, а у V фазі циклу спостерігалося різке (до максимального значення) зростання $\left(3633,63 \pm 492,61\right.$ мл $\left.\cdot \mathrm{xв} \cdot \mathrm{M}^{-2} ; \mathrm{p}<0,05\right)$. Разом 3 тим, ударний індекс (УІ) виявив слабку фразову динаміку: у першій половині циклу (I, II, III фрази) його параметри перебували практично на одному рівні, незначно зменшувались у IV фазі і вірогідно зростали тільки у $V$ фразі ( $<0,05)$.

Отже, встановлено залежність показників системної гемодинаміки обстежуваних фрутболісток від фраз біологічного циклу. Найбільш вираженою була фразова залежність показників ЧСС та МхАТ, найменшою - показників УІ, РТ та ЗПОС. Параметри СІ протягом ОМЦ змінювалися хвилеподібно, зростаючи від найменших значень, які спостерігались при овуляторній фразі циклу. Найвищі показники ЗПОС були у II і III фразах, найнижчі - у IV-V. Водночас параметри, які підлягали змінам, їхні цифрові значення, характер фразових коливань мали певні особливості: у III та V фазах циклу було помітне суттєве зменшення МхАТ та його розрахункових похідних; найвищі значення $\mathrm{CO}, \mathrm{XOK}$ та $\mathrm{Cl}-\mathrm{y} \mathrm{V}$ фазі біологічного циклу. Окрім того параметри ЗПОС в II і IV фразах перебували практично на одному рівні ( $p<0,05)$. Вказане, безсумнівно, свідчить про значний вплив занять фрутболом на стан центральної гемодинаміки.

\section{Висновки}

1. Аналіз електрокардіограм, зареєстрованих у різні фрази ОМЦ, дозволив встановити особливості перебігу біоелектричних процесів у серцевому м'язі 18-20-річних фрутболісток у стані спокою, після фрізичного навантаження та після відновлення і підтвердив, що міокард фуутболісток диспонує достатніми потенційними ресурсами і адаптаційними можливостями.

2. Стан центральної гемодинаміки обстежених фрутболісток 18-20 років значною мірою залежить від гормонального статусу. Фазові коливання найбільше впливають на параметри ЧСС та МхAT, найменше - на показники РТ, УІ, ЗПОС. Найвищі значення показників МхАТ та МуAТ у фрутболісток в овуляторній (III) та передменструальній (V) фазах ОМЦ ( $<<0,05$ щодо аналогічних параметрів в I та II фразах), показники ЧСС - найбільші у передменструальній (V) та менструальній (I) фазах циклу. Зазначене вказує, що у I, III та V фразах ОМЦ серцево-судинна система зазнає додаткового навантаження.

Перспективи подальших досліджень. Враховуючи, що жіночий фрутбол належить до тих видів спорту, які динамічно розвиваються, доцільно розширити діапазон досліджуваних міжсистемних кореляційних зв'язків, зокрема, за рахунок показників реографії / реоенцефалографії. 


\section{Література}

4. Будзин В. Р. Удосконалення навчально-тренувального процесу футболісток у підготовчому періоді з урахуванням фраз ОМЦ: метод. рекомендації / В. Р. Будзин, О. І. Рябуха. - Л.: Ліга-Прес, 2009. - 84 с.

2. Будзин В. Р. Особливості динаміки показників системи зовнішнього дихання у фрутболісток протягом фраз оваріально-менструального циклу / В. Будзин // Молода спорт. наука України: зб. наук. пр. з галузі фріз. культури та спорту. - 2009. - Вип. 13, Т. 3 - С. 23-29.

1. Будзин В. Р. Особливості взаємозв'язків між показниками ффункціонального стану організму футболісток у різні фрази специфічного біологічного циклу / В. Р. Будзин / Педагогіка, психологія та медико-біол. проблеми фріз. виховання і спорту; ред. С. С. Єрмаков, 2009. - № 5. - С. $20-32$.

6. Будзин В. Р. Динаміка ігрової діяльності та спеціальної підготовленості футболісток у різні фрази ОМЦ / В. Р. Будзин, О. І. Рябуха, Р. М. Пелехатий // Здоровий спосіб життя: [зб. наук. ст.]. 2009. - Вип. 42. - С. 7-12.

5. Будзин В. Р. Диференційовані підходи до навчальнотренувального процесу футболісток у підготовчому періоді з урахуванням фаз ОМЦ / В. Будзин // Вісник Чернігів. нац. пед. ун-ту імені Т. Г. Шевченка. Серія: Пед. науки. Фіз. виховання та спорт. - Чернігів, 2011. - Вип. 86, Т. 2. C. $23-27$.

3. Будзин В. Кореляційні портрети біоелектричної діяльності міокарда у футболісток 18-20 років у різні фази ОМЦ / Будзин Віра, Рябуха Ольга, О. Гузій // Фіз. культура, спорт та здоров'я нації: зб. наук. пр. - Вінниця, 2011. Вип. 12, т. 2. - С. 45-50.

7. Дембо А. Г. Спортивная кардиология / А. Г. Дембо, Э. В. Земцовский. - Л. : Медицина, 1989. - 463 с.

8. Похоленчук Ю. Т. Современный женский спорт / Ю. Т. Похоленчук, Н. В. Свечникова. - К.: Здоров'я, 1987. 192 c.

9. Радзиевский А. Р. Физиологическое обоснование управления спортивной тренировкой женщин с учетом фаз менструального цикла / А. Р. Радзиевский, Л. Г. Шахлина, 3. Р. Яценко, Т. П. Степанова // Теория и практика фриз. культуры. - 1990. - № 7. - С. 47-50.

10. Шахлина Л. Г. Медико-биологические основы спортивной тренировки женщин / Л. Г. Шахлина. - К.: Наук. думка, 2001. - С. 20-95.

11. Shachlina L. Functional state, physical fitness of top women athletes, based on medical - biological characteristics of the fermale body / L. Schachlina // Lectures Given in the seminar of the IAAF Moscow Regional development. Dedicated to «Gear of Women Athletes». - Moscow: Int. Amateur athletic Federation, 1998. - P. 51-58.

\section{References}

1. Budzyn V. R. Improving of training process for female football players at the preparation period, taking into account the phase of menstrual cycle: methods reccomendations / V. R. Budzyn, A. I. Ryabukha. - Lviv: Liga-Press, 2009. - 84 p.

2. Budzyn V. R. Features dynamics of external respiration system of female football players during the phases of menstrual cycle / V. Budzyn // Young sports science Ukraine: Coll. Sciences for Physical. Culture and Sport. - Lviv, 2009. 13, Vol. 3 - P. 23-29.

3. Budzyn V. R. Features connection between indicators of the functional state of female football players at different phases of a specific biological cycle / V. R. Budzyn / Pedagogy, psychology, medical-biological problems of physical education and sports science. Ed. S. Ermakov, 2009. - N 5. - P. 20-32

4. Budzyn V. R. Dynamics of competitive and specially training processes for female football players at the different phases of menstrual cycle / V. R. Budzyn, A. Ryabukha, R. M. Pelehatyy / / Healthy Living [Coll. sciences. themes.]. 2009. - Vol. 42. - P. 7-12.

5. Budzyn V. R. Differentiate approach to the training process for female football players at the preparation period, taking into account the phase menstrual cycle / V. R. Budzyn// Bulletin of Chernigov National Pedagogical Univ. of Taras Shevchenko. Series: Teaching Science. Physical education and sport. - 2011. - Vol. 86, v. 2. - P. 23-27.

6. Budzyn V. Correlation portraits of myocardium bioelectrical activity for female football players 18-20 years at the different phases of menstrual cycle / V. Budzyn, O. Ryabukha, O. Guzy // Physical Culture, Sports and Health of the Nation: Coll. sciences. etc. - Vinnitsa, 2011. - 12, Vol. 2. - P. 45-50.

7. Dembo A. G. Sports Cardiology / A. G. Dembo, E. V. Zemtsovsky. - L.: Medicina, 1989. - 463 p.

8. Poholenchuk T. Modern female sport / T. Poholenchuk, N. Svechnikova. - Kiev: Zdorovia, 1987. - 192 p.

9. Radzievskii A. R. Physiological basis for regulation of female sports training taking to account the phases of the menstrual cycle / A. R. Radzievskii, L. G. Shakhlina, Z. R. Yatsenko, T. P. Stepanova // Theory and Practice nat. culture. - 1990. - N 7. - P. 47-50.

10. Shakhlina L. G. Biomedical basis of female sports training / L. G. Shakhlina. - Kiev: Naukova dumka, 2001. P. 20-95.

11. Shakhlina $L$. Functional state, physical fitness of top women athletes, based on medical - biological characteristics of the female body / L. Shakhlina / / Lectures Given in the seminar of the IAAF Moscow Regional development. Dedicated to «Gear of Women Athletes». - M.: Int. Amateur athletic Federation, 1998. - P. 51-58. 